\title{
The ACRL Annual Report, 1954-55
}

\section{College Libraries in 1955}

$\mathrm{L}$ IKE HIS PRESIDENT, the college librarian looks to the future with increasing concern because of the enormous enrollment increase which has already begun. This will require building expansion, staff expansion, and tremendous book fund increase for the inevitable new fields of study and the extension of graduate work.

While the college librarian plans for growth in all directions, he must likewise reorient his attitudes toward librarianship. Service is not enough. The college library must be a positive educational force. This need is sensed, rather than well understood, by leaders in education of today, and in part accounts for the feeling of irritation, without important complaint, which so often centers on the academic library.

Listen to an unusually well informed elder statesman, the director of the Educational Policies Commission, and his colleague:

Except for a very few institutions, libraries have not played the role which they could play and which they should be encouraged to play in college life. The library is a magnificent academic resource too frequently used mechanically, with its services, and activities limited to the provision of books for reading in courses, and with its educational initiative limited. Inadequate use of the library must be regarded as inefficient use of available resources, and charged against poor college administration. ... The college administration, the faculty, and the library staff all have responsibilities for the development of increasingly imaginative educational service on the part of the library as a central feature of the academic environment with as yet unrealized potential.1

In this kindly criticism the authors join with other leaders in recognizing that the quality of education depends on the quality of the faculty and the quality of the library. Attention has focused on the former in re-

1 Howard E. Wilson and Gordon E. Samson, "The College Library in World Affairs." Journal of Higher Education XXVI (Dec. 1955), 486. cent years, but more attention is now being given to the library. We may soon be as much discussed a problem as teaching salaries. If so, college libraries will operate under the spotlight of investigations, frontpage publicity, and the speeches and papers of both politicians and research workers.

The primary need of the college and university library, as seen from the ACRL office, is for faculty understanding of the library's educational role and for the enlightened cooperation of faculty members and administrators. Likewise, the library staff needs better information on teaching methods and assignments so that cooperation can be mutual. The college library as the book center of the institution is, or should be, of equal concern to the teaching staff and the library staff. The librarian is, of course, responsible for administration and the library staff is in charge of operation, but his efforts cannot be very successful unless buttressed by purposeful faculty-student contact among the tools of learning, and by counsel and assistance at many points of library operation. The need for regular faculty contact with students in the library cannot be overemphasized, and is even more important as student bodies grow larger. Contact will at times extend to detailed suggestions about the use of indexes, bibliographies and related tools. Much of it is simple, friendly book chat. Contact with faculty stimulates student interest in intellectual subjects, provides guidance in choice of books and help in the use of difficult tools.

On the other hand, too many libraries operate without any sure first-hand staff knowledge of the daily routine in the classroom. There are assigned reading lists at the reserve desk. Perhaps one or two staff members do teach or take courses, but this is not enough. Some staff member in even the very small college library should have a pretty precise knowledge of teaching methods, coverage and assignments in the principal undergrad- 
uate courses. This knowledge is essential to meeting the responsibility of furnishing students with the tools of learning. Furthermore, knowledge of and interest in the teaching process and its problems will help foster faculty cooperation in the library program and its problems.

If members of faculties visualize college and university libraries in terms of the generation when they were graduate students, the fault is ours. Change has come and horizons must be lifted.

It is generally recognized that librarians do not write enough for the outside world and prepare too many papers for themselves. Our profession has some 250 journals and library publications of one type or another in this country alone. Our faculties, administrative officers and general public cannot be blamed for their lack of understanding of library objectives if we do not take the pains to publicize the library mission. This is at once the responsibility of each head librarian and the state and national library associations.

The solution to this need will not be easily found, but we will have the help of a great body of wise and unselfish leaders of education. Likewise, we share with the whole world of education the second major problem of librarianship, expanding enrollments which will double the size of colleges in fifteen years.

Student body expansion will increase the needs for everything. I believe the principal immediate library pressure will be for more reading room space in which students may study. It is inevitable that some institutions will have to turn students away from the library because of lack of space. To what purpose the whole educational process when student use of books, the pay-off of the whole process, is curtailed by this relatively inexpensive requirement of space to read?

An indirect result of expanding enrollment is expanding curriculum. Each year some junior colleges become senior colleges. Senior colleges take on some or more graduate study. Universities establish additional professional schools and extend doctoral study into new fields. Any such growth should be preceded by extensive purchase of the materials of study. The librarian must do everything possible to prevent his institution from taking on new fields until it has provided funds for the necessary tools.

Finally, with expansion facing us at every turn, we likewise have a crisis in staff to operate college libraries. There are not enough trained personnel for the present needs and the situation grows daily worse. The profession is unable to maintain standards for education and training. We may confidently expect an increase of 40 per cent in the number of college librarians by 1970. Where will they come from? Certainly the library schools are not providing for any such increase. Recruiting lags because salaries are so low, because very little effort is expended in this cause, and because some top positions have recently gone to people who have not worked up through the ranks but stepped into librarianship from college teaching and administrative positions.

College librarians are with justice criticized for their lack of advanced graduate work.

Unfortunately, this situation will continue so long as library salaries remain far below those of the teaching profession. Our future labor supply will undoubtedly be picked up here and there and everywhere. Only those institutions with better than average pay scales will have qualified library staffs.

In the final analysis, the solution of all professional problems and future growth depends on the quality and training of personnel. We need a large force of superior recruits who will spend several years in graduate study. To have this, librarianship must pay generous salaries up and down the professional scale. Let us forget once and for all the penny-pinching minimum salary scales for which librarianship is so well known. These may save a few dollars for the present but they inevitably throttle professional development.

These and other uncertainties of the future deserve careful thought. Meanwhile, let us consider the road recently traveled by the Association.

\section{The Presidential Program}

At the beginning of the year President Lyle adopted a four-point program which called for: closer relations between ACRL and the various learned societies and educational, professional and accrediting associa- 
tions; publication of an ACRL organization manual; a placement service; an improved program of work and social activity for the annual conference.

Very little progress was made with the first and third goals. A committee was established to foster closer ties with learned societies but had minor progress to report at the year's end. The placement service so greatly needed could not be established because legal advisors believed that the service might cause cancellation of ALA's tax-exempt status. Therefore, ACRL's brave attack on the placement problem faded away, and its only accomplishment was a strong.endorsement of the newly established Placement Exchange.

Of the four points in Mr. Lyle's program, most progress was made with the planning of the Philadelphia Conference. Work began on this early in the fall when your secretary and Mr. Alphonse Trezza, chairman of the Conference Programs Committee, attended a council on conference techniques in New York. Thereafter, planning proceeded rapidly and the June program was well established at the Midwinter meeting.

ACRL's part in the Philadelphia Conference would have been outstandingly successful had the weather not been so very hot. There was a good mixture of social and recreational events with professional programs. An expensive exhibition of rare books was financed by proceeds from a very popular moonlight sail on the Delaware. Small discussion groups called Circles of Information were enthusiastically received. The Rare Book Committee's program was outstanding. The association is indebted to the University of Pennsylvania for the use of its facilities and for the services of many of its library staff, and particularly the hard work and imagination of Alphonse Trezza.

The organization manual was begun in February and the principal contributions completed shortly therafter. General editorial work was placed in the hands of Joseph W. Kraus, and manuscript was to be reviewed by the chairman of the Publications Committee. The manuscript was ready for production in July, but publication was delayed by summer vacations and by the resignation of the ACRL publications officer in September.

\section{The United States Steel Foundiation} GRANT

Easily the outstanding event of the year for the association was the award of $\$ 30,000$ from the United States Steel Foundation to support college libraries and for research. The purposes of this grant and its handling have already been reported in c\&RL. While the sum awarded is small for national distribution, the event may well lead to important regular fund-raising activity. The association is greatly indebted to the foundation for the grant, and even more indebted for the counsel and support of Dr. W. Homer Turner, director of the foundation, an academician as well as a man of affairs with wide experience in and knowledge of research libraries, who conceived the plan, won the support of his board, and then wisely advised ACRL on its assignment of the money and its program of further support for libraries. Surely our "man of the year" for 1955 is W. Homer Turner.

\section{LIBRARY SURVEYS}

The ACRL office had general leadership and supervision for two surveys of libraries under formal ALA contracts. Early in $\mathbf{1 9 5 5}$ the Association received a request for a library survey from the North Shore Congregation Israel, a reformed synagogue in a Chicago suburb. After some discussion, responsibility for the survey was assigned to ACRL. Your secretary visited the synagogue, discussed survey coverage and prepared a plan which was accepted. It was expected that a surveyor of the Hebrew faith with the proper professional background would be found, but no one residing near Chicago was available to do the work. As a result, your secretary took leave of absence, gathered the information and wrote the report. This was mimeographed by the synagogue and a few copies are available for loan from the ACRL Office.

The United States Naval Academy at Annapolis requested a survey of its library at about the same time. After some correspondence and a visit to the academy, your reporter prepared a plan and budget for this study, which were accepted. Jack Dalton of the University of Virginia and William Dix of Princeton were selected as surveyors. Actual survey work was not undertaken until after 
the close of the current year. The academy has requested that the report on its library be confidential.

In addition to these two contracts, the office has advised a number of institutions on surveys and is always ready to recommend competent surveyors.

One bright spring day was spent at the University of Notre Dame Library, whose survey was completed about two years previously. It was extremely interesting to compare "then" with "now" and review with the librarian each recommendation of that survey in the light of his experience.

ALA has a statement of policy which governs surveys. A modest supervisory fee is charged, of which two-thirds is assigned to the division which takes leadership in the survey. In most cases institutions which inquire about surveys are advised to have this done officially by ALA. The objectivity and the added weight of recommendations by a national organization are important factors in favor of an official survey. From all evidence, surveys made in the past under the ACRL office have more than satisfied the contracting parties. The ALA and ACRL executive secretaries believe this to be an important service to the profession, but this view is not shared by all senior headquarters staff members and ACRL alone has undertaken surveys in recent years.

It is regretted that so very few college libraries undertake surveys. These need not be expensive. Many colleges badly need the advice of a competent outsider in redirecting their library program to increase its educational effectiveness.

\section{MEMbership AND FinANCES}

The year brought practically no change in the membership picture. There were 5,163 members, an increase of 45 over 1954. Allotments from membership dues totaled \$22,863.93.

The division spent nearly $\$ 4,800$ more than it received during $1954 / 55$. The actual deficit is considerably less than that because some major credit was in hand but could not be entered in the books until shortly after the year's end. The directors had budgeted $\$ 7,405$ of its reserve funds to finance the year's program. On August 31, 1955, the division had a cash balance of $\$ 8,584.43$. Two years ago the ACRL balance was nearly twice this sum. The reduction in cash balance is the result of board policy to invest division funds in an expanded program.

During the year the treasurer turned over to the ALA comptroller all ACRL funds and financial records. The ALA treasurer's report incorporates full information on the use of ACRL funds. ACRL members are referred to that report for details on finances of the division.

\section{Publications}

The official journal, COLLEGE AND RESEARCH LIBRARIES, continues to be a chief contribution to the profession and a principal service to the membership. The association is ever more deeply indebted to Dr. Maurice F. Tauber for his uncompensated services as editor. Similar recognition is due to the editor's principal assistants, C. Donald Cook and John Rather, and to the editorial board.

A questionnaire on C\&RL was sent to the membership with the annual ballot. This elicited a great deal of constructive criticism and considerable praise for the journal. An analysis of the replies was published in the issue for January 1956.

C\&RL did well financially. Advertising income was up nearly $\$ 1,500$ from last year's figure of $\$ 5,258$. Other income decreased slightly. Total income was $\$ 10,062.50$. Expenses (excluding salaries of headquarters personnel) were $\$ 13,022.97$. The difference between expense and income was, of course, made up by an appropriation from ACRL's general funds.

Progress with the ACRL Monograph and Microcard series is reported by the Publications Committee. The Monographs ended the year with a deficit of $\$ 800$, principally because the manufacturing cost of No. 14 falls within the current year but sales did not begin in volume until after the year's end. Publication of this volume (Rothstein's Development of Reference Services) is a major step forward, as it is certainly the most important and the most ambitious publication in the series. Monograph accounts receivable plus inventory of stock in hand (valued at 50 per cent of sales price) represent assets of approximately $\$ 4,000$. 
Travel

Considerably more time and money was spent in travel on association business and less on visits to libraries and state association meetings than in previous years.

Principal library meetings attended were the conferences of the Pacific Northwest Library Association at Tacoma, the New England Library Association at Swampscott, and the ACRL Philadelphia Chapter at Rosemont. Numerous individual libraries were visited in connection with these and other trips.

\section{Consultation}

A considerable portion of the secretary's time is devoted to correspondence and personal discussion of problems at individual libraries. These problems cover a wide range of professional topics, but more time was devoted to building plans than to any other single subject. Hardly a week passes without one or more letters and interviews with college administrators, architects and librarians on this subject. The ALA library and ACRL committees perform similar services of great value.

\section{ACKNOWLEDGMENTS}

During the past year the ACRL office has become indebted to the ALA staff generally for a pleasant and cooperative working relationship, and particularly to Mrs. Stevenson and Mr. Clift. Mrs. Spigelman resigned as publications officer shortly after the year's end. She will be missed. Miss Mitchell continues as the office secretary, efficient and productive in daily work. Her sharp eyes and even disposition have prevented many a minor shipwreck.

This report would not be complete without public recognition to Joseph Shipman for three years of service as treasurer. During this time he had an increasing daily burden in receiving funds and making disbursements. This responsibility was discharged with regularity, care and discernment at considerable personal sacrifice.

Finally, your reporter must record personal gratitude to President Lyle for his cooperation this past year. It was much more than one could expect. Of greater importance is, of course, the fine leadership he gave to the association as its president.

Those who wish further information on the affairs of the association during the year should consult the brief of minutes of the directors' meetings in the April and October 1955 issues of C\&RL. The Summary Reports of 1955 Midwinter Meetings (ALA, 1955) and 74th Annual Conference Proceedings of the ALA (ALA, 1955) give further data. Vital statistics are given in the organization issue (December) of the ALA Bulletin.

Much of the following material was prepared by section and committee chairmen, whose initials are used to indicate authorship.

\section{Sections}

\section{College Libraries Section}

\section{Ruth K. Porritt, Chairman}

The activities of the section for this year centered in joint programs at Midwinter with the University Libraries Section and at the annual conference with the Junior College Libraries Section as well as the University Libraries Section. The joint effort of these groups provided an evening meeting at Midwinter and a morning program at Philadelphia. No committees were active and no projects undertaken.

(R.K.P.)

\section{Junior College Libraries Section}

Nellie M. Homes, Chairman

The two principal projects for the year were the continued study of standards for junior college libraries and the collection of statistics.

A revision of the standards was presented by the Standards Committee at the ALA Midwinter meeting. The consensus was that the valuable report did not meet the needs of all types of libraries. It was noted that the problems of liberal arts, residential colleges differed from those institutions with technical or vocational curricula. Catherine Cardew was appointed chairman of a subcommittee to make recommendations to the Standards Committee. In May the revised report was distributed to the membership and to nonmember junior colleges along with member- 
ship promotion material. Copies of the standards were sent to regional accrediting associations.

The revised standards were discussed at the annual conference in Philadelphia but were again referred to the committee, with Miss Elizabeth Neal as chairman, for further revision and work upon points of disagreement brought out at the meeting.

The junior college statistics were collected and tabulated by Mrs. Thelma Vogt Taylor. They were prepared for publication with the assistance of Mrs. Cynthia Spigelman, ACRL Publications Officer, and were published in the January issue of COLLEGE AND RESEARCH LIBRARIEs. At the Midwinter meeting of the ACRL Statistics Committee, it was decided that junior college libraries would in the future receive the regular ACRL statistics form, and that the junior college member of the ACRL committee would be responsible for tabulating the section statistics.

One newsletter was issued. This included ballot, Standards Committee report, news, and program for the Annual Conference.

(N.M.H.)

\section{Pure and Applied Science Section} Jane Ganfield, Chairman

A committee headed by Mrs. Margaret Bryant is at work on the "Recommended List of Basic Periodicals in the Agricultural Sciences," which will be published as an ACRL Monograph.

At the Midwinter meeting the membership considered a request for reproduction of the catalog of the U. S. Waterways Experiment Station at Vicksburg, Mississippi. The U. S. Army Corps of Engineers might reproduce this if an official request were sent them. The section membership referred the matter to the board of directors. Following correspondence between the Station and ACRL headquarters, the request was granted.

\section{Reference Librarians Section}

Elizabeth M. Bond, Chairman

The year's program for the section was discussed at an October meeting in Chicago attended by the chairman, the director for this section, and the ACRL executive secretary. Committees were appointed in good season.
The Committee on Wilson Indexes (Jerome $\mathrm{K}$. Wilcox, chairman) is a joint committee with the Public Libraries Division. Membership is drawn from the New York area. The group met frequently and deserves a vote of thanks from the whole profession for its steady progress.

The new Committee on Interlibrary Loans (Henry M. Fuller, chairman) has made important progress with plans to facilitate international interlibrary loans. (Mr. Fuller's tragic death from polio this fall is a great loss to the profession.)

The Midwinter Meeting program was a panel discussion on the proposed changes in the catalog code, or "What the Reference Librarian Expects of the Card Catalog." At the annual conference in Philadelphia Colton Storm spoke on the importance of local history materials.

The adoption by the ALA Council at the Philadelphia Conference of the Management Survey, with its important implications for reference librarians in all types of libraries, has resolved one of our most pressing problems: whether or not to urge the establishment of a reference division of the American Library Association. The section has had a committee working to find out the wishes of the section membership for two years. The implementation of the Management Survey will see all reference librarians together in one functional group.

Special thanks should be expressed to the other officers of the section; to the chairmen and members of the various committees; to our out-going director, Miss Florence M. Gifford, who has served us so devotedly; and to Mr. Arthur T. Hamlin and his staff, always ready with understanding help and advice.

(E.M.B.)

\section{Libraries of Teacher Training Institutions Section \\ Marion B. Grady, Chairman}

The program for the year was discussed at a conference attended by the chairman, chairman-elect and ACRL executive secretary last fall. The program for Midwinter was also determined at this time.

The Committee on Bibliographical Research (Walfred Erickson, chairman) is planning a cooperative indexing project. This will be presented to the membership later. 
The Committee on Standards (R. F. Schaupp, chairman) is at work on the development of concrete standards.

(A.T.H.)

\section{University Libraries Section}

Richard H. Logsdon, Chairman

The section undertook no special activities this year. The Midwinter program dealt with the financial problems of college and university libraries. At the ALA annual conference the joint program sponsored by three sections (university, college and junior colleges) was on undergraduate library service.

(A.T.H.)

\section{Committees}

\section{Audio-Visual Committee}

Louis S. Shores, Chairman

A directory of A-V personnel in college libraries was published in mimeographed form. COLLEGE AND RESEARCH LIBRARIES brought out the first of a series of the new feature, "A-V Clearing House," edited by the committee.

At the ALA pre-conference A-V Institute the committee put on a session for college librarians. It sponsored a Circle of Information on AV problems. Nine types of equipment were available for demonstration.

The committee's mission has been redefined. The Committee has cooperated with DAVI by reviewing two drafts of DAVI's Brochure No. 4.

The committee is considering two proposals for film production: (a) there is urgent need for a freshman orientation film on library use, and the committee will seek a sizable sum to finance this; (b) the need for a good recruitment film for the profession is universally expressed, and ACRL should assist in this project needed by the whole profession.

\section{Committee on Committees}

\section{N. Orwin Rush, Chairman}

The ACRL Committee on Committees carried on most of its work by correspondence. Each member of the committee prepared a list of possible candidates for committee membership. In addition, the chairman solicited suggestions from all officers of the ACRL. These lists were gone over at a meeting of the entire committee at the time of the midwinter meeting of ALA, and final recommendations were passed on to President-elect Robert Vosper.

(N.O.R.)

\section{Duplicates Exchange Union \\ Whiton Powell, Chairman}

Membership of Duplicates Exchange Union continues at approximately 120 . All but eight expressed the desire to continue through replies to a questionnaire sent out this spring. Annual turnover of membership averages about 5 per cent, and continues the trend toward smaller libraries.

(W.P.)

\section{Publications Committee \\ Jerrold Orne, Chairman}

The efforts of this committee during 195455 have been devoted exclusively to clarifying the financial management of the various publication efforts of ACRL and obtaining a revision of policy statements concerning each publication to bring them closer to the goals of ACRL. Some effort was expended to bring about normalization of the Editorial Board responsibility for each publication or series.

C\&RL issued its normal four issues, and in addition a five-year index covering the period 1950-54, which was distributed in April, 1955. The July, 1955, issue contained for the first time a section dealing specifically with audio-visual materials edited by Louis $\mathrm{S}$. Shores. It is expected that this will be a regular feature of the journal.

The ACRL Monographs extended its list by three titles during 1954-55, one of which was ACRL's first full-length bound book. Sales continue good and the financial status of this series is strong.

The ACRL Microcard Series now contains 50 items and has on hand 65 standing orders. Abstracts are published regularly in COLLEGE AND RESEARCH LIBRARIES, as well as other periodicals for which a particular item has in- 
terest. The Editorial Committee has been expanded and the policy of subject matter inclusion redefined.

\section{Committee on Rare Books, Manuscripts and Special Collections Gerald D. McDonald, Chairman}

In 1953-54 a committee was appointed to explore the need for some organization within the ALA which would reflect the interests of rare book librarians. In June, 1954, the Committee on Rare Books, Manuscripts and Special Collections was established officially as a permanent committee of ACRL.

In its first year the committee realized that it must make itself known among those rare book librarians who were not closely associated with the work of ALA and ACRL. Letters and news notes were sent to various library and bibliographical periodicals, while a longer article giving something of the committee's history, present program and aspirations was prepared for COLLEGE AND RESEARCH LIBRARIEs by Miss Hannah French. The influence of this promotional work could be seen at the first program meeting of the committee, which was held at Philadelphia. It attracted many people who seldom come to our conventions. The subject of the meeting was "Buying Rare Books and Manuscripts for Libraries," and its theme was developed by Mary A. Benjamin, Jacob Zeitlin and Ellen Shaffer.

Business meetings were held on January 31 in Chicago and on July 6 in Philadelphia. At the first meeting, a statement of purpose was read, revised and approved. The problem of service charges made by university business offices in handling monies given to libraries had been placed before the committee. A statement of policy was drafted and later endorsed by the ACRL Board of Directors. At the July meeting, plans for the preparation of a practical manual on the handling of rare books in libraries were outlined and an editor was appointed.

(G.D.M.)

\section{Recruiting Committee}

Eugene P. Watson, Chairman

The committee concentrated most of its attention on working with and encouraging other groups engaged in recruiting. By un- derwriting a major portion $(\$ 100)$ of the cost, the committee assisted Alpha Beta Alpha, the national undergraduate library science fraternity, in publishing a publicity leaflet. The committee also prepared and submitted to the Norman Bassett Foundation two proposals for publicizing Alpha Beta $\mathrm{Al}$ pha.

The committee subsidized $(\$ 48)$ the program of the Joint Committee on Library Work as a Career. The two committees collaborated in an attempt to produce a recruiting pamphlet for the use of guidance counselors; when the Joint Committee finally abandoned the proposal toward the end of the year, the Recruiting Committee took over the project as its own.

The chairman of the committee wrote a recruiting article for Education magazine, answered several letters from ACRL members relating to various phases of recruiting, and presided over the discussion of recruiting in the Circles of Information at Philadelphia.

(E.P.W.)

\section{Committee on Standards}

William H. Jesse, Chairman

Members of the ACRL Committee on Standards continue work on projects initiated at the 1955 Midwinter meeting. Eli Oboler is chairman of a subcommittee preparing a monograph to present under one cover the standards of the several regional accrediting associations, as well as a bibliography of writings on college library standards compiled by David Weber. The committee decided not to include junior college standards in this publication, which is tentatively set for January, 1956.

A cooperative study of standards in relation to a few college libraries has been initiated by Miss Helen Brown, and Wayne Yenawine (new chairman of the committee) is working on a determination of a valid percentage increase to be applied to the dollar figures cited in the Library Score Cards and Classification and Pay Plans to allow for inflation factors.

Dr. A. L. McNeal was chairman pro tem for the committee meeting at Philadelphia, to which members of the Junior College Libraries Section were invited.

(W.H.J.) 
ACRL State Representatives

Archie L. McNeal, Chairman

The ACRL State Representatives continued their work with primary emphasis on membership. Some plans were considered with regard to placement problems but were held in abeyance following the development of Foster Mohrhardt's Library Placement Service. At the conclusion of the year Miss Mary D. Herrick assumed responsibility as chairman of the State Representatives.

(A.L.McN.)

\section{Committee on Statistics}

Dale M. Bentz, Chairman

The ACRL Statistics Committee held meetings at both the Midwinter and Annual Conferences of the American Library
Association. The results of the committee's efforts can be seen in the January issue of COLLEGE AND RESEARCH LIBRARIES.

This year the committee assumed the responsibility of collecting audio-visual data for the ACRL Audio-Visual Committee, and also incorporated the junior college statistics as part of its work. The committee also recommended to the ACRL executive officers that the statistical data be reproduced photographically.

Fifteen hundred questionnaires for the collecting of the 1954-55 data were sent to some 700 different libraries. The amount of time required to audit, interpret and compile this mass of information is tremendous. This year the committee was composed of a representative from each group of libraries, and each members was responsible for the compilation of his group.

(D.M.B.)

\section{Chapters}

\section{Illinois State Chapter}

William V. Jackson, Chairman

The Illinois Chapter, the College and Research Libraries Section of the Illinois Library Association, held its annual meeting on November 5, 1954, in Springfield. Miss Martha Biggs, chairman, presided.

The program consisted of a symposium on . college library problems. Dr. William V. Jackson spoke on "Improving Services to Readers," Miss Nellie R. Stickle on "Weeding the College Library," and Mr. Ferris S. Randall on "Economies in Order Work." A discussion period followed the papers.

After a report from Mr. Benjamin B. Richards and comments from members present, it was agreed to continue exploration of the possibility of regional meetings of the college, university and research librarians in the Midwest.

The following were elected as officers for 1954-55: Dr. Jackson, Chairman, and Miss Ruth Gilley, Secretary.

(W.V.J.)

\section{New Jersey State Chapter \\ Theodore Epstein, President}

The year was marked by an increase in membership of over 35 per cent and corre- spondingly high attendance at two meetings. On October 30, 1954, at Centenary Junior College in Hackettstown, a record number of members turned out to participate in a business meeting, a steak dinner, and a panel discussion of "So You Can't Interest Students in Books?" A tour of the new Taylor Memorial Library, dedicated only a week prior to the meeting, was a highlight of the day.

At the annual spring conference of the state association in Asbury Park the section acted as host to all of NJLA with a novel coffee hour. A meeting later that day featured a report of the work done toward liberalizing interlibrary loans and stressed better service to students residing in the area of certain libraries, but attending other institutions. Dr. Felix E. Hirsch, newly appointed librarian of the State Teachers College in Trenton, spoke on the work of the Regents' Committee on Integration of College and University Library Resources in New York State, with a view toward a similar study being made in New Jersey. Newly elected officers are: President, William S. Dix, librarian, Princeton University; Vice-President and President-elect, Miriam Grosh, librarian, Upsala College; Secretary-Treasurer, Juliette A. Trainor, librarian, State Teachers College, Paterson.

(T.E.) 